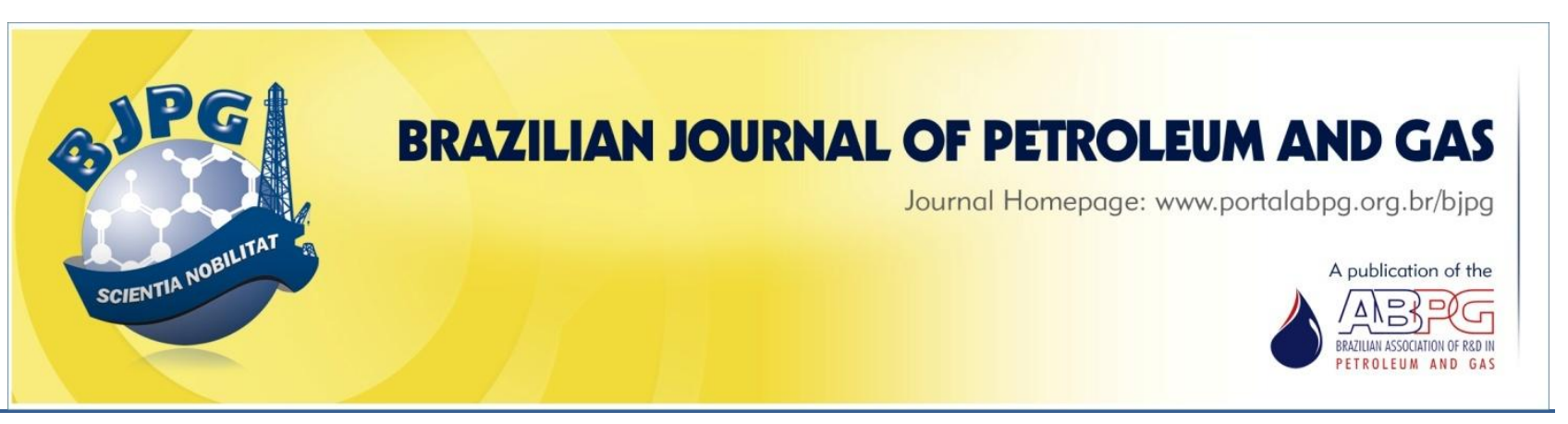

\title{
CALCULATION OF THERMAL RADIATION FOR THE DESIGN OF PROTECTION AND FIRE FIGHTING SYSTEMS FOR LPG STORAGE PARKS
}

\author{
${ }^{\text {a }}$ Martins, R. M. S. T. ${ }^{1}$; ${ }^{\text {a Vianna, R. F. }}$ \\ ${ }^{a}$ Federal University of Bahia, Graduate Program of Chemical Engineering, Salvador - BA, Brazil \\ Received: 23.11.2019 / Revised: 28.03.2020 / Accepted: 31.03.2020 / Published on line: 06.05.2020
}

\begin{abstract}
Liquefied petroleum gas (LPG) is industrially stored in spherical or cylindrical vessels. These follow strict construction standards to prevent accidents that may be caused by fire or explosions in neighboring equipment. The heat transfer by thermal radiation is LPG's main fire propagator. However, even with standards in place, design and operational failures can still occur. In this context, the installation of firefighting systems to avert major disasters becomes critical. The design of these systems must follow national and international standards and codes, which indicate prescriptive criteria for the selection of equipment to be cooled in case of fire in a LPG storage park. The present paper presents a case study for a LPG spherical vessel storage park. It uses the ALOHA simulator to calculate the action radius of thermal radiation and subsequent selection of spheres to be cooled. It also compares standards adopted in Brazil to international standards, demonstrating that Brazilian standards are more conservative and obsolete in regards to the advances in Fire Engineering. The work has the potential to be used as the basis for reviewing Brazilian's standards.
\end{abstract}

\section{KEYWORDS}

ALOHA; LPG; firefighting; design; storage park

\footnotetext{
${ }^{1}$ To whom all correspondence should be addressed.

Address: Federal University of Bahia, Graduate Program of Chemical Engineering, R. Prof. Aristides Novis, 02, 2ㅇ andar, Federação, Salvador - BA, Brazil

ZIP Code: 40210-630 | Phone number: +55(71)98794-4334 | e-mail: rsatelles29@gmail.com doi:10.5419/bjpg2020-0004
} 


\section{INTRODUCTION}

The industry stores Liquefied Petroleum Gas (LPG) in cylindrical or spherical vessels distributed in areas denominated storage parks. Specifications and the construction of cylinders and spheres, as well as the pipes that transport LPG, follow strict regulations to avoid accidents such as fire and explosion (Raj, 2005).

According to Fontenelle (2012), fires or explosions are likely to occur when vapors or liquids are released in places where an ignition source may exist, or where an ignition source is introduced into an area with a flammable atmosphere.

The occurrence of fire in an industrial facility contributes to degradation of mechanical properties of metal structures, causing loss of structural strength and possible equipment failure. These hazards are caused mainly by heat transfer from thermal radiation. Industrial accidents represent a damaging factor in many sectors, posing a constant threat of human loss, equipment damage, and environmental impact that can cost millions of dollars (Samia et al., 2018).

When a fire occurs in a pressured sphere storing LPG and the equipment is exposed to flame, it must be cooled to minimize the fire action, so the internal pressure does not increase to dangerous levels, reaching material rupture pressure (PETROBRAS, 2003, apud Santos, 2007, p. 20). For the reasons listed above, it becomes critical the installation of firefighting systems, following established rules and procedures.

In Brazil, fire safety standardization was introduced late; lagging behind and with discrepancy from Asian countries, European countries, Canada, and the US (Claret \& Mattedi, 2011). Presently, Brazil remains without a strong national legislation on fire protection and firefighting systems, whether for building installations (commercial and residences) or industrial facilities.

Studies involving industrial firefighting systems are less explored if compared to systems designed for residential and commercial buildings. This may be related to their complexity, since the industry encompasses facilities in which large volumes of combustible, flammable, and even toxic substances are produced and stored. Tabaczenski et al. (2017) present a summary of 16 fire safety studies in Brazil, of which only 2 refer to industrial areas, being both related to fuel tanks. Rodrigues (2016) presents a comparative study between technical regulations on fire safety and panic (Strategies for Crisis Intervention and Prevention- SCIP) within Brazilian states, with the main objective of evaluating the elaboration feasibility of national technical regulation. Nevertheless, the study does not analyze technical regulations for industrial areas.

In countries such as China, India, and Ecuador, specialists such as Chavéz (2015), Islam and Sultan (2017), and Lang et al. (2011) compared local laws to those of international reference agencies such as the National Fire Protection Association (NFPA) and the American Petroleum Institute (API). The authors concluded that these standards present gaps regarding the efficiency of design predicted parameters, exposing the precariousness of Fire Engineering studies in their home countries.

For oil and gas industries, the standards set by governments are based generally on Process Industry practices. Specifically for LPG facilities, API 2510 (API, 2011) and API 2510A (API, 2015) are used commonly internationally, which establish minimum distances for vessel spacings based on lessons learnt from accidents (Murthy \& Serikova, 2016). These standards also indicate the fire protection and firefighting methods to be used.

For firefighting systems in LPG storage parks in Brazil, the following standards are used: $\mathrm{N}-1203$ (PETROBRAS, 2013) of PETROBRAS and Technical Instruction (IT) \#28 of Brazilian Military Fire Departments (CBM) (CBM, 2014ab, 2017), such as the ones from Goiás, Paraná, and Bahia, are fundamentally prescriptive, which differ in some concerns.

When observing guidelines for the selection of equipment to be cooled in a LPG storage park, the API indicates an analysis of the thermal radiation flow generated by the fire, while Brazilian standards propose a selection based solely on a pre-established distance. 
Considering that research papers focusing on the regulation study of firefighting systems in Brazil related to industrial facilities are still incipient, we decided to develop a study of the thermal radiation flow impact based on various weather conditions in a LPG storage facility. The present study compares standards established in Brazilian to international standards. We used the free simulator ALOHA (Areal Locations of Hazardous Atmospheres). ALOHA is one of four programs of CAMEO (Computer Aided Management of Emergency Operations) developed by the American Environmental Protection Agency - EPA for the thermal radiation flow analysis. This modeling software assists professionals in obtaining important safety information, and it is used widely in research worldwide (Samia et al., 2018, Mišić et al., 2018; Perez, 2016; Tomasoni, 2010).

\section{MATERIALS AND METHODS}

\subsection{Thermal radiation flow}

Energy from thermal radiation (radiated by fire) through electromagnetic waves are the main responsible for compromising the structure of equipment and structures near the point where the leakage began (Seito et al., 2008). Thermal radiation flow knowledge in a facility is indispensable for a concise firefighting system design.

The effects of fires and explosions related to thermal energy and overpressure are studied widely, and their effects on people, structures, and environment are estimated by various research institutions. National standards, such as NT 01 (2017) of CEPRAM (Conselho Estadual de Meio Ambiente do Estado da Bahia) (CEPRAM, 2017); and international standards such as NFPA 59A (2016), API 521 (2014), 49 CFR (2018), and EN 1473 (2016) set parameters for thermal radiation flow and establish how these fires and explosions can be harmful to people, environment, and structures (Yi et al., 2019).

Several models and equations have been developed to calculate thermal radiation flow. In the model proposed by Carter, radiation is determined by multiple equidistant radiation points along the flame axis, considering that each point is emitting independent radiation with the same radiation power. Whazan's model, similar to Carter's, proposes five radiation source points along the flame (Seito et al., 2008). To aid in the complexity of radiation calculations, several computer programs have been created to calculate thermal radiation flow. Many of these software are paid or are for exclusive use of the company that created them, such as PHAST. Other software, such as ALOHA, are free (ALOHA, 2014). ALOHA is used vastly by industries, schools, fire brigade teams, environmental and government organizations in the USA and in many other countries (Mišić et al., 2018, Perez, 2016, Tomasoni et al., 2010).

ALOHA uses a solid flame empirical model developed by Shell Research (Chamberlain, 1987, apud Jones et al., 2013) in radiation calculations. Thermal energy incident on a distant target is a product of the flame's surface emissivity, geometric vision factor, and transmissivity of thermal radiation into atmosphere. The methods and equations used by the program, available in its technical manual, can be found on CAMEO internet platform.

Zio and Aven (2013) apud Samia et al. (2018) indicated that with this simulator "It is possible to simulate various source terms such as leaks, line ruptures, long pipeline releases and tank roof collapses to obtain desired consequence results, such as concentration at a given distance."

ALOHA has characteristics of various chemicals in its database. From information provided by the user at the simulation time about weather conditions and circumstances of the event, a graph, with regions identifying the risk areas as: toxicity, thermal radiation, flammability and overpressure, is generated (Perez, 2016).

The following methodology shall be followed to determine the radius of thermal radiation impact causing damage to equipment and people using the ALOHA simulator:

1. Selection of facility location;

2. Selection of building type and the vicinity;

3. Selection of chemical product (ALOHA does not work with mixtures);

4. Indication of weather parameters (wind speed and direction, nebulosity, atmospheric 
temperature, humidity). For this topic, it is indicated to make several analyses considering different possibilities of wind speed, humidity, and atmospheric temperature);

5. Selection of where the product is stored in facility (i.e. piping, vessel);

6. In case of vessel, the selection of type (cylindrical or spherical) and dimensions;

7. Indication of the product's physical state and its storage temperature;

8. Indication of the product's volume inside the vessel;

9. Selection of vessel failure type, under the following options:

- Leaking tank, chemical is not burning as it escapes into the atmosphere

- Leaking tank, chemical is burning as a jet fire

- BLEVE, thank explodes and chemical burns in a fireball;

10. Selection and indication of diameter or length where the leak is passing by;

11. Indication of leak location in relation of equipment (bottom or top, e.g., this parameter is indicated as a percentage of the equipment's height);

12. Selection the option Threat Zone, where some levels of thermal radiation flow are already parameterized ready to be edited.

Upon completion of these steps, the program generates a graph with the action radius of the selected thermal radiation flows and a screen with all data entered and the final results.

The thermal radiation flow generated by a fire is influenced by several factors, such as type of substance, volume stored (in piping or equipment), weather condition, leakage dimensions (equipment breakdown, line rupture), and ignition sources, among others (Seito et al., 2008). To evaluate the action radius of thermal radiation flow, local weather data should be used. The main weather data considered are: wind speed, atmospheric stability, and wind direction (Marx \& Cornwell, 2009). These three variables affect the size and extent of impact zones, as well as how impacts are mapped in the area around each release point. Robust risk mapping techniques demonstrate that the number of combinations between speed, stability, and wind direction significantly influence risk contours (Marx \& Cornwell, 2009).

In Brazil, the weather information pertinent to the region under study can be extracted from national institute of meteorology's (INMET) virtual address, where there is the BDMEP (Banco de Dados Meteorológicos para Ensino e Pesquisa), which is the database to support teaching, research activities, and other applications in areas such as meteorology, hydrology, water resources, public health, and environment. In some studies, meteorological data from neighboring cities may also be used, without prejudice to the analysis to be performed.

\subsection{Firefighting system design}

Stored fluid and the operating conditions of transport and storage should be known for firefighting system design in chemical storage facilities such as marine terminals, natural gas processing plants, factories, petrochemical facilities, and vessels parks. The facility layout is an essential factor because it will determine the exposure risk of neighboring equipment. For each type of fluid stored, there are specific regulations and laws. It is within the engineer's role to select the most suitable fluid for installation. From the standards selection, parameters (i.e. equations and rates) are extracted and the items necessary for firefighting system design are selected using simulators or spreadsheets.

For the equipment selection to be protected by cooling system in a LPG storage park, N-1203 (PETROBRAS, 2013) PETROBRAS standard and in Technical Instruction (IT) \#28 of Military Fire Brigade (CBM) (CBM, 2017) propose the cooling of spheres within $30 \mathrm{~m}$ (side to side) of another burning sphere or vessel. API 2510A (API, 2015) proposes to prepare a risk analysis of the installation so that critical fire cases can be predicted. This would also include scenarios where a burning sphere or vessel is adjacent vessels that should be cooled, indicating that vessels receiving more than $7000 \mathrm{btu} / \mathrm{h}_{\mathrm{ft}}{ }^{2}\left(22 \mathrm{~kW} / \mathrm{m}^{2}\right)$ should be cooled to avoid overheating and causing metal brittleness. 


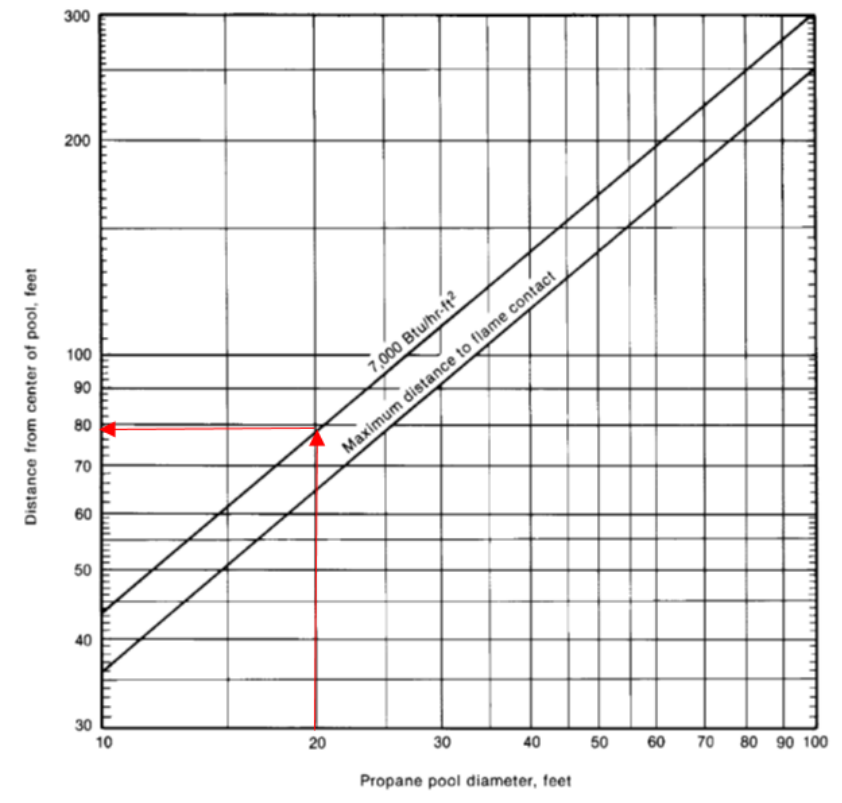

Figure 1. Pool fire thermal radiation flow. Source: API 2510 A (2015).

An analysis on thermal radiation was performed by Ramsden and Abusaieda (2017), based on the IP Safety Model of Practice Code, Part 19. The mentioned code suggests that if the radiation heat flow calculated is higher than $8 \mathrm{~kW} / \mathrm{m}^{2}$ in an adjacent tank, cooling water must be available by, in example, mobile systems. In this case, if the radiation flow is greater than $32 \mathrm{~kW} / \mathrm{m}^{2}$, a fixedacting cooling system must be installed immediately. The TNO Green Book (1992) indicates that the critical intensity of thermal radiation flow is $25 \mathrm{~kW} / \mathrm{m}^{2}$ for metallic surfaces, leading to deformations in structural elements.

In case of pool fire, API 2510 A (API, 2015) conservatively proposes the use of Figure 1 , in which, by identifying the diameter of the propane pool, one can find the distance between the center of the pool and the equipment that must be cooled, as it is subjected to a thermal radiation flow of $22 \mathrm{~kW} / \mathrm{m}^{2}$ or more. As an example, if the propane pool diameter is 20 feet $(6.1 \mathrm{~m})$, the distance between the equipment and the pool center where it is necessary to cool the equipment is 78 feet. $(23.8 \mathrm{~m})$. For this case, the $30 \mathrm{~m}$ indicated by Brazilian standards is more conservative.

The use of Figure 1 has some restrictions, and it may cause distortion since it was designed considering radiant heat from a propane pool fire exposed to a wind of 20 miles $/ \mathrm{h}(8.94 \mathrm{~m} / \mathrm{s})$ blowing directly under the vessel. These considerations are more conservative as they assume that the wind is blowing directly into the vessel and use propane data, which produces more radiant flames than other heavier hydrocarbons. The use of propane as a representative $L P G$ compound also is indicated by CETESB (2011).

The use of radiation flow equal to $22 \mathrm{~kW} / \mathrm{m}^{2}$, proposed by API $2510 \mathrm{~A}$ (API, 2015) to select the equipment to be protected by cooling system, is more conservative than indicated by Ramsden and Abusaieda (2017). However, it is in line with the standards and codes in which the harmful thermal radiation flow to metallic surfaces is indicated, as NFPA 59A (NFPA, 2016), API 521 (API, 2014), 49 CFR (CFR, 2018), EN 1473 (EN, 2016), and TNO Green Book (1992) apud Yi et al. (2019). Thus, this data is satisfactory for selecting the equipment to be cooled in a storage park.

\subsection{Case study: LPG spherical vessels storage park}

This topic presents the case study. It refers to a hypothetical LPG spherical vessels storage park to be installed in a new terminal at the region of Camaçari Petrochemical Complex in Bahia, an area of great industrial development in Brazil. The goal is to establish which equipment should be cooled in case of a fire in one of these spheres, considering the action radius of $22 \mathrm{~kW} / \mathrm{m}^{2}$ thermal 


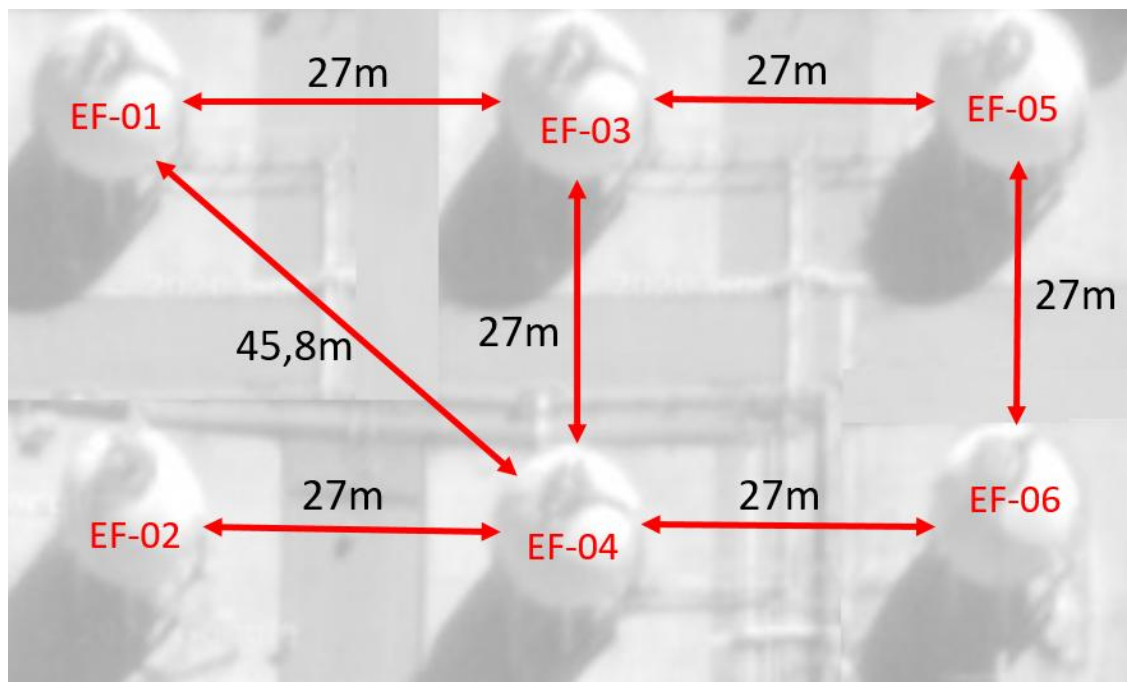

Figure 2. Top view of LPG spherical vessels storage park.

radiation flow, as proposed in API $2510 \mathrm{~A}$ (API, 2015) and the distance of $30 \mathrm{~m}$ (side to side) established in Brazilian standards.

The use of sphere storages is economically justified for keeping large volumes of LPG, reason why refineries or supply terminals are built with some spheres. In this case study, the park is composed of 6 spheres (EF-01, EF-02, EF-03, EF-04, EF-05 and EF-06), with $15 \mathrm{~m}$ of diameter, arranged in superior view, as one can observe in Figure 2. The use of 6-spheres park allows us to make strong analysis regarding the standards, since the impact proposed by the fire is applied to neighboring spheres, thus, becoming a satisfactory basic core for the analysis to be elaborated.

To evaluate a $22 \mathrm{~kW} / \mathrm{m}^{2}$ thermal radiation threat zone, the software ALOHA version 5.4.7 was used, replacing the use of Figure 1, proposed in API
2510 A (API, 2015). Figure 1 addresses pool fire and an unique weather condition and it does not use real data of the place analyzed.

The weather data required for the thermal radiation analysis were extracted from INMET database, using information from the city of Salvador, Bahia, since there is no available data available from the city of Camaçari. This analogy is satisfactory, since these are nearby cities and both are located at the All Saints Bay coastline, with little to no divergence regarding weather conditions. The data collected refers to a period from 01/01/2014 to 05/31/2019 and are shown in Table 1:

For the analysis of thermal radiation effect on the facility, we considered the effect caused by propane fire, a representative substance in this type of analysis for LPG, as indicated by Companhia

Table 1. Weather parameters from Salvador: period from 01/01/2014 to 05/31/2019 extracted from INMET.

\begin{tabular}{lc}
\hline \multicolumn{1}{c}{ Weather parameter } & Data \\
\hline Average of atmospheric temperature $\left({ }^{\circ} \mathrm{C}\right)$ & 25.5 \\
Average of relative humidity $(\%)$ & 82.2 \\
Average of wind speed $(\mathrm{m} / \mathrm{s})$ & 0.82 \\
Highest average of atmospheric temperature $\left({ }^{\circ} \mathrm{C}\right)$ & 32.8 \\
Highest average of relative humidity $(\%)$ & 99.5 \\
Highest average of wind speed $(\mathrm{m} / \mathrm{s})$ & 7.1 \\
Lowest average of atmospheric temperature $\left({ }^{\circ} \mathrm{C}\right)$ & 19.7 \\
Lowest average of relative humidity $(\%)$ & 65.5 \\
Predominant wind direction & East $(\mathrm{E})$ \\
\hline
\end{tabular}


Table 2. Scenarios of weather and spheres filling for LPG storage park.

\begin{tabular}{ccccc}
\hline Scenario & Humidity (\%) & Temperature $\left({ }^{\circ} \mathbf{C}\right)$ & Wind speed $(\mathbf{m} / \mathbf{s})$ & $\begin{array}{c}\text { Sphere filled with LPG } \\
\text { (\%) }\end{array}$ \\
\hline A & & & & 20 \\
B & 65.5 & 19.7 & 1 & 80 \\
C & 65.5 & 19.7 & 1 & 20 \\
D & 65.5 & 19.7 & 7.1 & 80 \\
E & 65.5 & 19.7 & 7.1 & 20 \\
F & 99.5 & 19,7 & 1 & 80 \\
G & 99.5 & 19.7 & 1 & 20 \\
H & 99.5 & 19.7 & 7.1 & 80 \\
I & 99.5 & 19.7 & 7.1 & 20 \\
J & 65.5 & 32.8 & 1 & 80 \\
K & 65.5 & 32.8 & 1 & 20 \\
L & 65.5 & 32.8 & 7.1 & 80 \\
M & 65.5 & 32.8 & 7.1 & 20 \\
N & 99.5 & 32.8 & 1 & 80 \\
O & 99.5 & 32.8 & 1 & 20 \\
P & 99.5 & 32.8 & 7.1 & 80 \\
\hline
\end{tabular}

de Tecnologia e Saneamanto Ambiental- CETESB (2011). The cause of the fire was a leakage on a 2 in drain line valve at EF-03 sphere bottom. This incident was selected based on the cause of a major accident in Feyzen (Kletz, 2013). Further studies of risk analysis using quantitative and qualitative methods should be performed at the facility to predict imminent risks, as proposed by Hefaidh et al. (2019), but are not part of the scope of this study.

Researches indicate that variations in facility weather conditions and equipment filling level impact thermal radiation flow (Fontenelle, 2012; Marx \& Cornwel, 2009; Atkinson et al., 2017; Seito et al., 2008; Raj, 2005). Considering these assumptions, simulations with different scenarios are proposed for: humidity, atmospheric temperature and wind speed, as well as sphere filling, as indicated in Table 2.

\section{RESULTS AND DISCUSSION}

Using ALOHA, it was possible to simulate the 16 scenarios proposed with different weather and sphere filling conditions, obtaining the largest action radius for thermal radiation flow equal to 22 $\mathrm{kW} / \mathrm{m}^{2}$ in scenarios $\mathrm{K}, \mathrm{L}$, and $\mathrm{P}$, whose radius was found to be $22 \mathrm{~m}$ as shown in Figures $3,4,5,6,7$, and 8 . All simulator results for the 16 simulated scenarios are shown in Table 3.
Looking at Table 3, we observe that for the proposed case of leakage in the 2 in drain line valve, at the bottom of one sphere with $15 \mathrm{~m}$ diameter, the variation in the filling degree $(20 \%$ and $80 \%$ ) does not impact the action radius of thermal radiation flows for most observed cases, except for cases $O$ and $P$ where the radius were 21 $\mathrm{m}$ and $22 \mathrm{~m}$, respectively. This demonstrates that humidity and wind speed, and the filling of the equipment impacts the action radius of thermal radiation flow in situations with higher temperature.

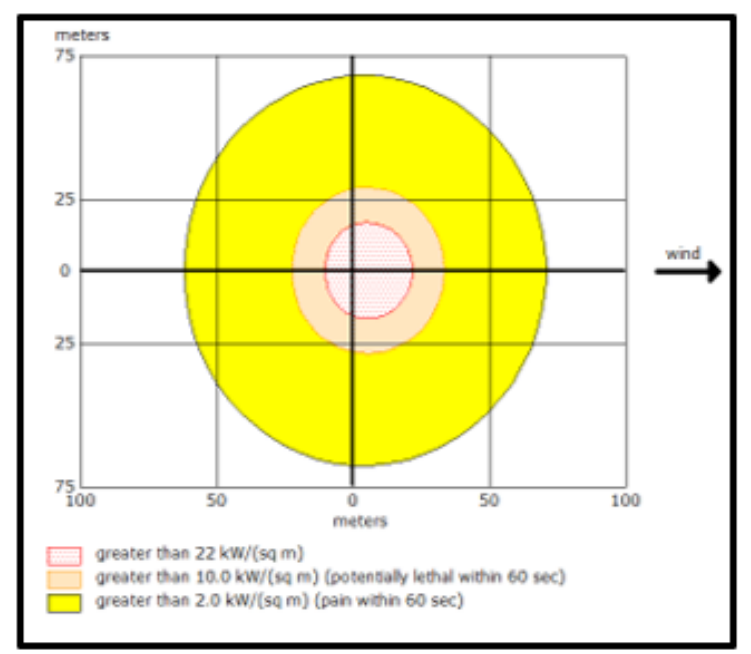

Figure 3. Threatened areas based on the intensity of thermal radiation - Scenario $\mathrm{K}$. 


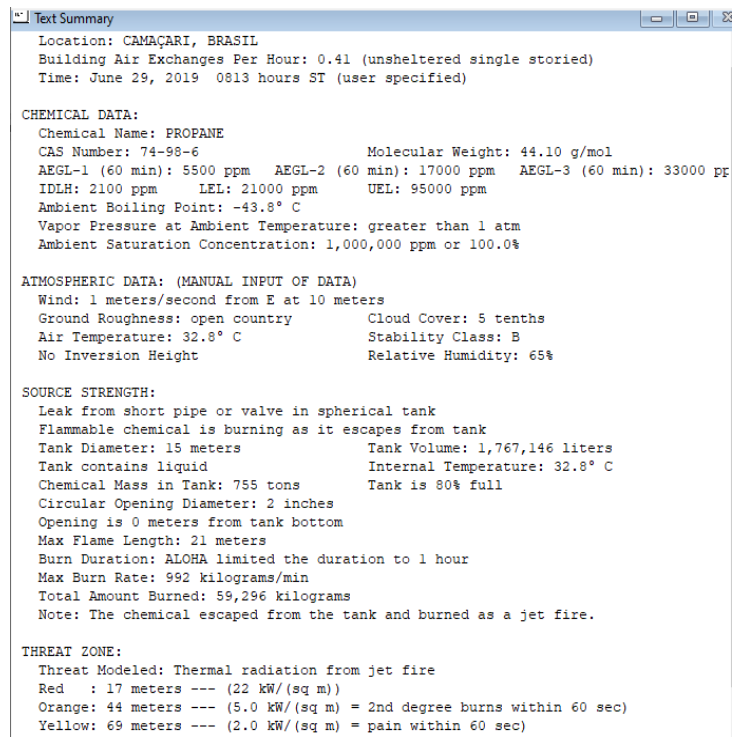

Figure 4. Scenario $\mathrm{K}$ - Simulation data.

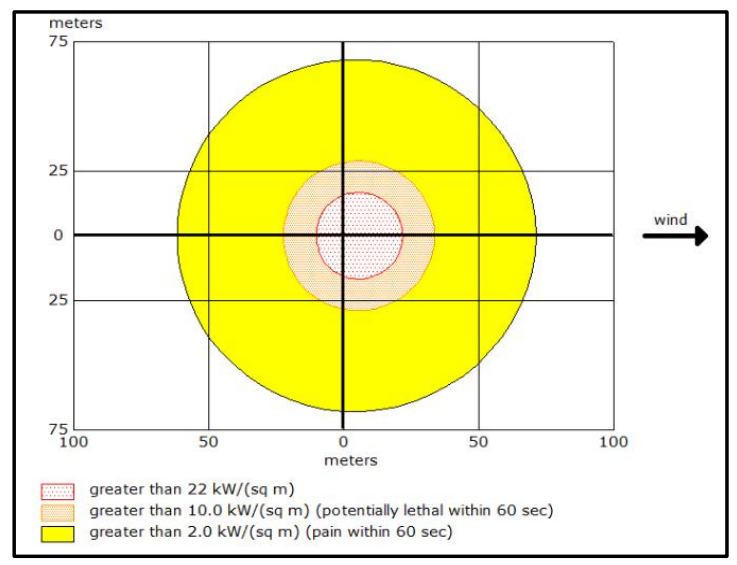

Figure 5. Threatened areas based on the intensity of thermal radiation - Scenario $\mathrm{L}$.

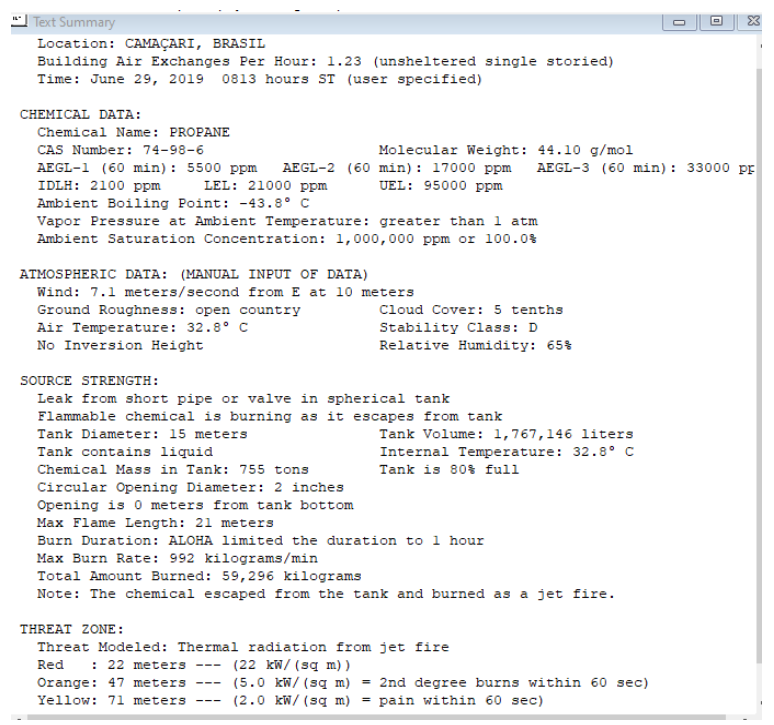

Figure 6. Scenario $L-$ Simulation data.

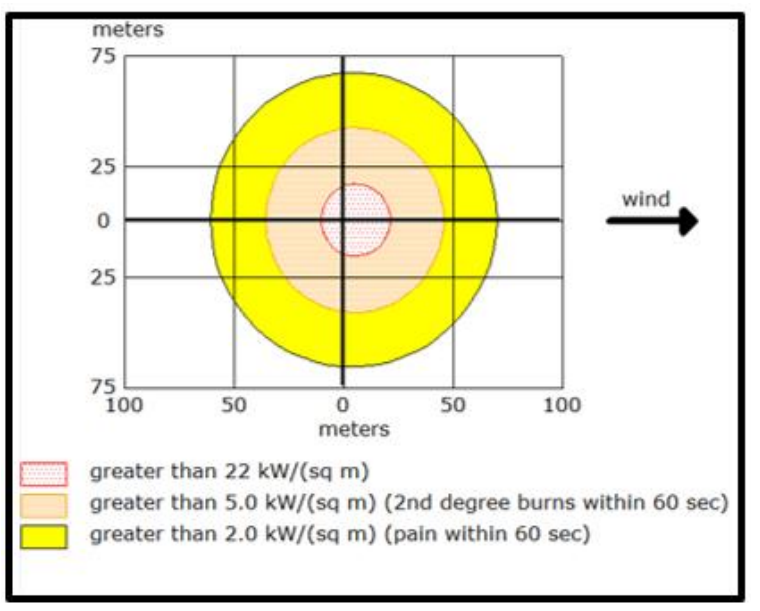

Figure 7. Threatened areas based on the intensity of thermal radiation - Scenario $P$.

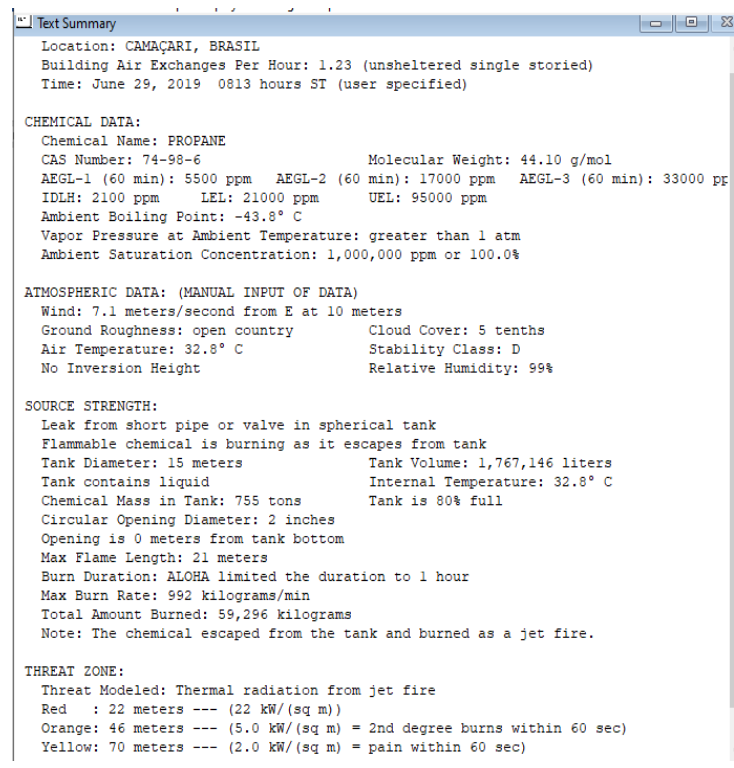

Figure 8. Scenario $\mathrm{P}$ - Simulation data.

The wind speed variation $(1 \mathrm{~m} / \mathrm{s}$ and $7.1 \mathrm{~m} / \mathrm{s}$ ) impacts the action radius of $22 \mathrm{~kW} / \mathrm{m}^{2}$ thermal radiation flow in all cases analyzed, demonstrating that higher speeds lead to a larger action radius. Humidity variation (65\% and 99\%) also impacts thermal radiation flow, but to a lesser extent than wind speed variation; the higher the humidity is, the smaller the action radius will be. The different atmospheric temperatures $\left(19.7^{\circ} \mathrm{C}\right.$ and $\left.32.8^{\circ} \mathrm{C}\right)$ analyzed also impacted the radius, but less predominantly than wind speed variation. The higher the temperature is the greater the radius will be. 
Table 3. Action radius of thermal flow results for scenarios regarding weather and spheres filling.

\begin{tabular}{|c|c|c|c|c|c|c|c|c|c|c|c|c|c|c|c|c|}
\hline Scenario & A & $B$ & C & $\mathrm{D}$ & $E$ & $\mathrm{~F}$ & $\mathrm{G}$ & $\mathrm{H}$ & I & $\mathrm{J}$ & $\mathrm{K}$ & $\mathrm{L}$ & $M$ & $\mathrm{~N}$ & 0 & $P$ \\
\hline $\begin{array}{l}\text { Action radius }(\mathrm{m}) \\
\text { for thermal } \\
\text { radiation flow of } 22 \\
\mathrm{~kW} / \mathrm{m}^{2}\end{array}$ & 16 & 16 & 21 & 21 & 15 & 15 & 20 & 20 & 17 & 17 & 22 & 22 & 17 & 17 & 21 & 21 \\
\hline
\end{tabular}

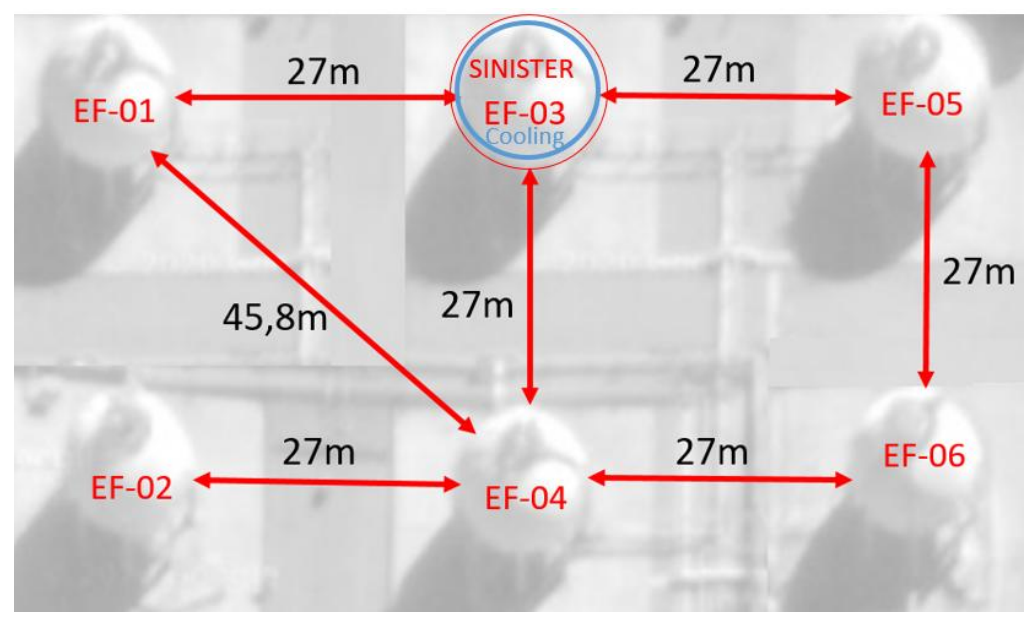

Figure 9. Representation of the distance between the spheres and the sinister in EF-03 as indicated in API-2510A (2015).

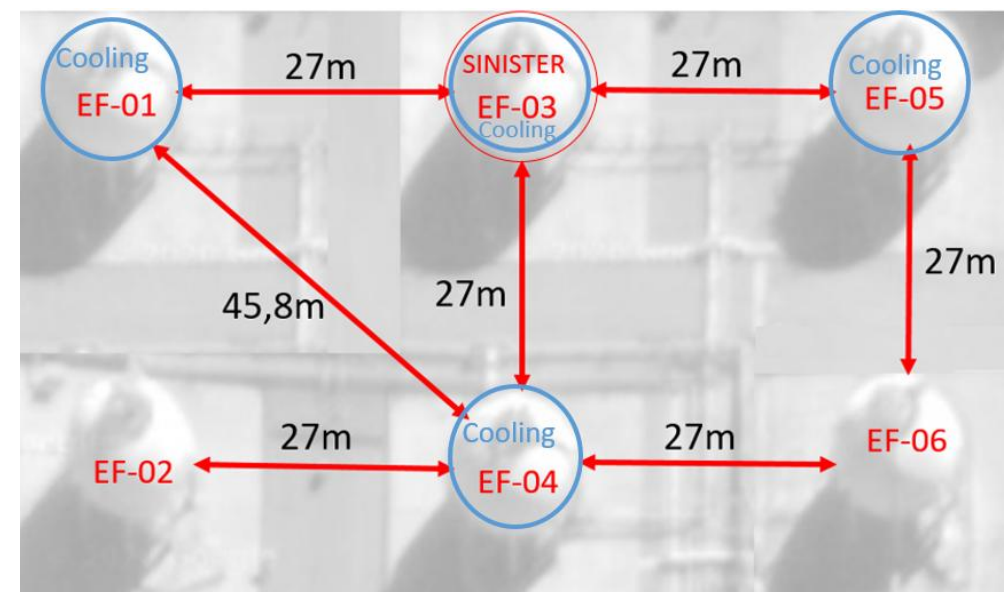

Figure 10. Representation of the distance between the spheres and the sinister in EF-03 as indicated in IT \#28 of CBMBA (CBM, 2017) and N-1203 (PETROBRAS, 2013).

The largest radius found for the $22 \mathrm{~kW} / \mathrm{m}^{2}$ thermal radiation flow, which was $22 \mathrm{~m}$ (scenarios $K, L$, and $P$ ), is the radius that should be used to select the spheres to be protected in case of fire in one of any spheres at the storage park under study. Note that the radius found is less than $30 \mathrm{~m}$ proposed by IT \#28 of CBMBA (CBM, 2017) and N1203 of PETROBRAS (PETROBRAS, 2013).
For the layout of the installation under study, we notice that the shortest distance between the spheres (side to side) is $27 \mathrm{~m}$. Therefore, for selection of the equipment to be cooled according to API 2510A (API, 2015), it should be considered only the sphere on fire as indicated in Figure 9. Based on Brazilian standards, the worst case would be the fire in EF-03 sphere and cooling of EF-01, EF04, and EF-05 spheres, as shown in Figure 10. 


\section{CONCLUSIONS}

In this study, a hypothetical LPG spherical vessels storage park was evaluated to establish which equipment should be cooled in case of fire in one of the spheres, considering the action radius of $7,000 \mathrm{btu} / \mathrm{h} . \mathrm{ft}^{2}\left(22 \mathrm{~kW} / \mathrm{m}^{2}\right)$ thermal radiation flow, as proposed in API $2510 \mathrm{~A}$ (API, 2015) and the $30 \mathrm{~m}$ (side to side) distance established in Brazilian standards.

As evaluating the action radius radiation of 22 $\mathrm{kW} / \mathrm{m}^{2}, 16$ scenarios were analyzed using the ALOHA simulator. In these scenarios, we considered weather conditions (humidity, wind speed and atmospheric temperature) of the place under study, and two possibilities of sphere filling to cover the largest number of possibilities to find the worst scenario, i.e., larger action radius of thermal radiation flow. The most significant data was the wind speed, with larger radius being found for $22 \mathrm{~kW} / \mathrm{m}^{2}$ thermal radiation flow, when higher wind speeds were used. As a result of this analysis, the largest radius found was $22 \mathrm{~m}$ for scenarios $\mathrm{K}$, $L$, and $P$.

Thus, for installation studied and according to international standard API 2510A (API, 2015) we found the need for cooling only the burning sphere. However, according to the criteria established by Brazilian standard N-1203 (PETROBRAS, 2013) of PETROBRAS and IT \#28 (2017) of Corpo de Bombeiros Militar da BahiaCBMBA, similar to other Brazilian Fire Departments, we identified the fire in sphere EF-03 and the need for cooling spheres EF-01, EF-04 and $\mathrm{EF}-05$ as the worst scenario.

The present study demonstrates that the Brazilian standards are more conservative and obsolete in face of the advancements in the field of Fire Engineering. This leads to increased costs in firefighting system implementation, without necessarily making the installation more protected than the dimension considering real risks. The international standard, when proposing the assessment of the action radius impact of thermal radiation flow, is more realistic, making the design more reliable and protected, without under or over dimensioning the risks.

A point that could be reviewed in API standard is the indication of Figure 1 , by determining the action radius of $22 \mathrm{~kW} / \mathrm{m}^{2}$ thermal radiation flow for pool fire without direct flame. Since Figure 1 was prepared considering propane and wind burning at $20 \mathrm{miles} / \mathrm{h}$, and no other weather conditions that impact thermal radiation as well as other types of fire. This study proposes, as a solution, the use of the free software ALOHA, or another simulator with recognized performance, to consider the local weather condition to make the firefighting system design more realistic and, therefore, more reliable.

Our findings corroborate the statement by Murthy and Serikova (2015) that establishes that the challenges of facilities implantation are unique to each design; and engineering standards, best practices, and legal requirements are intended to meet minimum requirements, and should not be taken as an absolute value.

\section{ACKNOWLEDGMENTS}

The authors would like to recognize Conselho Nacional de Desenvolvimento Científico $e$ Tecnológico (CNPq) and the Graduate Program in Chemical Engineering from the Federal University of Bahia for the support provided to accomplish this work.

\section{REFERENCES}

ALOHA. US Environmental Protection Agency, National oceanic and atmospheric administration, Version 5.4.7, 2014.

API - AMERICAN PETROLEUM INSTITUTE. API 2510: Design and Construction of LPG Installations. Washington: API, 2011.

API - AMERICAN PETROLEUM INSTITUTE. API 2510A: Fire-Protection Considerations for the Design and Operation of Liquefied Petroleum Gas (LPG) Storage Facilities. Washington: API, 2015.

Atkinson, G.; Cowpe, E.; Halliday, J.; Painter, D. A review of very large vapour cloud explosions: Cloud formation and explosion severity. Journal of Loss Prevention in the Process Industries, v. 48, p. 367-375, 2017.

https://doi.org/10.1016/i.jp.2017.03.021 
CBM - CORPO DE BOMBEIROS MILITAR DO

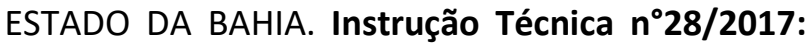
Manipulação, armazenamento, comercialização e utilização de gás liquefeito de petróleo (GLP). Bahia, 36p., 2017. (in Portuguese)

CBM - CORPO DE BOMBEIROS MILITAR DO ESTADO DE GOIÁS. Norma Técnica n²8/2014: Gás liquefeito de petróleo (GLP) - PARTE 1 Manipulação, utilização e central de GLP. Publicado no BGE n 205/2014, Goiânia, 27p., 2014a. (in Portuguese)

CBM - CORPO DE BOMBEIROS MILITAR DO ESTADO DO PARANÁ. Norma de Procedimento Técnico $\quad n^{\circ}$ 28/2014: Manipulação, armazenamento, comercialização e utilização de gás liquefeito de petróleo (GLP). Paraná, 42 p., 2014b. (in Portuguese)

CEPRAM - Conselho Estadual de Meio Ambiente do Estado da Bahia. NORMA TÉCNICA NT 01: Análise e Gerenciamento de Risco Acidentais para Substâncias Perigosas. Bahia: 2017. (in Portuguese)

CETESB - Companhia de Tecnologia e Saneamanto Ambiental. Norma Técnica P4-261: Risco de Acidentes de Origem Tecnológica Método para decisão e termos de referência. São Paulo. $2^{\text {nd }}$ Edition, 2011. (in Portuguese)

Chamberlain, G. A. Developments in design methods for predicting thermal-radiation from flares. Chemical Engineering Research \& Design, v. 65 (4), p. 299-309, 1987.

Chavéz, S. R. M. Evaluación del nivel de riesgo y propuesta de um sistema contra incendios para tanques de almacenamiento de gas licuado de petróleo para minimizar el riesgo de incendio y explosión. Trabajo de Grado (Magister en Seguridad y Salud Ocupacional). Universidad Internacional SEK, Quito, 2015.

Claret, A. M.; Mattedi, D. L. Estudo da prescritividade das normas técnicas brasileiras. Revista Escola de Minas, 64(3), p 265-271, 2011. (in Portuguese) https://doi.org/10.1590/50370$\underline{44672011000300003}$
Fontenelle, F. M. A. Análise térmica em estruturas de tanques de armazenamento de etanol em situação de incêndio. Dissertação (Mestrado em Engenharia Civil). Universidade Federal do Rio de Janeiro, Rio de Janeiro, 2012. (in Portuguese)

Hefaidh, H., Djebabra, M.; lila, S.; Mouna, T., Contribuition to the evaluation of safety barriers performance. World Journal of Science, Tecnology and Sustainable Development, v. 16(1), p. 56-68, 2019. https://doi.org/10.1108/WJSTSD-08-2018-0055

Islam, K.; Sultan, S. Industry Best Practice Risk based design for LPG facility: Gap in Bangladesh practice. Journal of Chemical Engineering, v. 30(1), p. 8-11, 2017. https://doi.org/10.3329/ice.v30i1.34790

Jones, R.; Lehr, W.; Simecek-Beatty, D.; Reynolds, R. M. ALOHA (Areal Locations of Hazardous Atmospheres) 5.4.4 - Technical Documentaion, Seattle-USA, 2013.

Kletz, T. O que houve de errado? Casos de desastres em plantas de processo e como eles poderiam ser evitados. Tradução Claudio Kierzner Dorfman - Rio de Janeiro: Inteciência, 2013. (in Portuguese)

Lang, Xu-Qing; Liu, Quan-Zhen; Gong, Hong. Study of Fire Fighting System to Extinguish Full Surface Fire of Large Scale Floating Roof Tanks. Engineering Procedia, n.11, p. 189-195, 2011. https://doi.org/10.1016/i.proeng.2011.04.646

Marx, J. D.; Cornwell, J. B. The importance of weather variations in a quantitative risk analysis. Journal of Loss Prevention in the Process Industries, n. 22, p. 803-808, 2009.

https://doi.org/10.1016/i.jp.2009.08.009

Mišić, N.; Zigar, D.; Božilov, A.; Pešić, D. Calculation of thermal radiation level during a pool fire caused by leakage of kerosene from tanker wagon at railway crossings. Safety Engineering Series, v. XIII (1), p. 29-36, 2018.

https://doi.org/10.2478/tvsbses-2018-0005

Murthy, M.; Serikova, N. Selection of failure frequency and its impact on risk assessment: A case study from plot plan optimization. Journal of Loss Prevention in the Process Industries, v. 44, p. 690698, 2016. https://doi.org/10.1016/j.jlp.2016.05.001 
Perez, R. C. Emergências Tecnológicas. $2^{\text {nd }}$ Ed. Sorocaba: Gráfica Editora Cidade, 354 p., 2016. (in Portuguese)

PETROBRAS. N-1203: Projeto de sistemas fixos de proteção contra incêndio em instalações industriais terrestres. Dez. 2013 (Rev F). (in Portuguese)

Raj, P. K. Exposure of a liquefied gas container to an external fire. Journal of Hazardous Materials, v. 122 (1-2), p 37-49, 2005.

https://doi.org/10.1016/j.jhazmat.2005.04.004

Ramsden, N.; Abusaieda, K. A study of water cooling using different water application techniques to protect storage tankwalls against thermal radiation. Process Safety and Environmental Protection, I 09, p.577-598, 2017. https://doi.org/10.1016/i.psep.2017.04.009

Rodrigues, E. E. C. Sistema de Gestão da Segurança contra Incêndio e Pânico nas Edificações: Fundamentação para um Regulamentação Nacional. Tese (Doutorado em Engenharia Civil). Universidade Federal do Rio Grande do Sul, Porto Alegre, 2016. (in Portuguese)

Samia, C.; Hamzi, R.; Chebila, M. Contribution of the lessons learned from oil refining accidents to the industrial risks assessment. Management of Environmental Quality: An International Journal, v. 29(4), p. 643-665, 2018.

https://doi.org/10.1108/MEQ-07-2017-0067

Santos, E. F. Identificação de hipóteses e cenários de acidentes ampliados em uma unidade de engarrafamento de gás liquefeito de petróleo através de APP. 2007. 64 p. Monografia de conclusão de Curso (Pós-Graduação em Engenharia e Segurança do Trabalho). Universidade de Pernambuco, Recife. (in Portuguese)
Seito, A. I.; Gill, A. A.; Pannoni, F. D.; Ono, R.; Silva, S. B.; Del Carlo, U.; Silva, V. P. A Segurança contra incêndio no Brasil. São Paulo: Projeto Editora, 2008. (in Portuguese)

Tabaczenski, R.; Côrrea, C.; Santos, M. M. L.; Pires, T. A. C.; Silva, J. J. R. Aplicação do software fire dynamics simulator (FDS) no estudo da segurança contra incêndios ( $\mathrm{SCl}$ ) no Brasil. Revista FLAMMAE, v. 3(7), p. 87-116, 2017. (in Portuguese)

TNO - The Netherlands Organization of Applied Scientific Research. Methods for the determination of possible damage to people and objects resulting releases of hazardous materials "Green Book". 3a ed. The Hague: Committee for the Prevention of Disasters, 1992.

Tomasoni, A. M.; Galbolino, E.; Rovatti, M; Sacile, R. Risk evaluation of real-time accident scenarios in the transport of hazardous material on road. Management of Environmental Quality: An International Journal, v. 21(5), p. 695-711, 2010. https://doi.org/10.1108/14777831011067962

Yi, Hang.; Feng, Yu.; Wang, Q. Computational fluid dynamics (CFD) study of heat radiation from large liquefied petroleum gas (LPG) pool fires. Journal of Loss Prevention in the Process Industries, v. 61, p.262-274, 2019. https://doi.org/10.1016/i.jp.2019.06.015

Zio, E; Aven, T. Model output uncertainty in risk assessment. International Journal of Performability Engineering, v. 9(5), p. 475-486, 2013. 